\title{
Species Distribution of Styrax sumatrana in North Sumatra Using Maxent Modelling Approach
}

\author{
M. Hadi Saputra ${ }^{1^{*}}$, Saut Aritua Hasiholan Sagala ${ }^{2}$, Han Soo Lee ${ }^{3}$ \\ ${ }^{1}$ Environmental and Forestry Research and Development Agency of Aek Nauli, Sibaganding, \\ Simalungun, North Sumatra, Indonesia \\ ${ }^{2}$ Bandung Institute of Technology, Bandung, West Java 40132 , Indonesia \\ ${ }^{3}$ Graduate School for International Development and Cooperation, Hiroshima University, 1-5-1 \\ Kagamiyama, Higashi-Hiroshima 739-8529, Hiroshima, Japan \\ *) Corresponding Author (e-mail: mhadis.ms@gmail.com)
}

Received: 18 October 2019 / Accepted: 16 January 2020 / Published: 17 January 2020

\begin{abstract}
Styrax sumatrana is the prestigious tree from North Sumatra. The resin which is a product from this tree has high demand and take a role as the primary income for farmer around the forest. However, the climate change along with the land conversion, threatens the species distribution. This paper aims to analyse the variable that contributes to Styrax sumatrana distribution and predict the potential distribution area of the species in North Sumatra Province . Several variables, such as elevation, slope, aspect, climate condition and land use land cover (LULC), were used to analyse the contribution for Styrax sumatrana distribution. The analysis uses the Maximum entropy model to examine the variable contribution for species distribution. The result shows that the mean temperature of the coldest quarter has a higher contribution for species distribution followed by elevation and LULC. The climate condition has a great impact by $28.5 \%$ than the other variable. The potential area that is suitable for Styrax sumatrana distribution was $8.91 \%$ or around $663,221.94$ ha from a total of region.
\end{abstract}

Keywords: Climate Change, Species Distribution Models, Styrax Sumatrana, Maximum entropy.

Abstrak. Styrax sumatrana merupakan jenis pohon andalan di Sumatera Utara. Kemenyan yang merupakan produk dari resin Styrax sumatrana bernilai tinggi dan menjadi sumber pendapatan utama bagi para petani kemenyan di sekitar hutan. Namun, perubahan iklim dan konversi lahan menjadi tantangan bagi sebaran species ini. Tulisan ini bertujuan untuk menganalisa variabel yang berperan dalam penyebaran kemenyan di Sumatera Utara dan memprediksi luasan area yang berpotensi untuk penyebaran jenis ini. Beebrapa variabel dikumpulkan untuk analisa. Variabel tersebut antara lain ketinggian, kelerengan, arah lereng, kondisi iklim dan tutupan lahan. Maximum entropy (Maxent) model digunakan untuk menganalisa variabel yang penting dalam sebaran jenis kemenyan. Hasil menunjukkan suhu rata-rata pada kuarter musim dingin berperan penting pada sebaran jenis kemenyan, diikuti oleh ketinggian dan tutupan lahan. Perubahan iklim berdampak lebih besar dengan nilai $28,5 \%$ dibandingkan variabel lainnya. Jumlah area yang berpotensi untuk sebaran kemenyan adalah $8,91 \%$ atau sekitar $66.221,94$ hektar dari total area Sumatera Utara.

Kata kunci: Perubahan iklim, Species Distribution Models, Kemenyan, Maximum entropy.

\section{Introduction}

Styrax sumatrana as one of the nontimber product trees in North Sumatra is the source of Sumatra benzoin. Sumatra benzoin is the resin produced from the bark of Styrax sumatrana. The resin is used in many types 
of products, such as pharmacy, food, industry and also in a traditional ceremony (GarcíaFernández, Casado, \& Ruiz Pérez, 2003; Jayusman, 2014; Silalahi \& Sunandar, 2017). This species is distributed along the North Sumatra mostly around Lake Toba Catchment Area (LTCA) (Sunandar, 2012). It is common to see the species as a garden plant in North Sumatra Province. Having this species in a garden is valuable and important since it can become an additional income for farmers around the forest. Moreover, the gardens could support the biodiversity in the forest area that protects the forest from the disturbances (García-Fernández et al., 2003).

Recently, the distribution of this species has threatened by the land use changes and the change in the climate condition. The changes might shift the distribution of the species in the future as well as the reducing the quality of its gum (Anas \& Kholibrina, 2017a, 2018; Kholibrina, Anas, \& Susilowati, 2018). Furthermore, the area may be changes into more valuable land use such as crop, industrial or residential (Gaol \& Simangunsong, 2012). The threat from valuable crop plantation may convert the Styrax garden and reduced the population (García-Fernández et al., 2003).

The effort to protect the Styrax sumatrana habitat needs the support from the species distribution information (Miller, 2010). The environmental requirement for the species to survive need to be known as well as the spatial location for the species to distributed. The variable also needs the existing location of the species (Prasad et al., 2016). This action will lead the conservation strategies to determine the potential location for Styrax sumatrana. Species Distribution Models (SDMs) are models that predict the geographical maps of species suitability in the area by calculating the correlation of known between occurrence records and the environmental condition at the area (Gomes et al., 2018). SDMs use to analyze the variable that gives the contribution for Styrax sumatrana distribution and provide the information of suitable area for it to spread. SDMs use three components: an ecological model, a data collection model, and statistical model which is the algorithm in modelling approach to classifying the probability of species distribution as a function of a set of environmental variables (Austin, 2007). Several approaches that used for SDMs are Maxent (Phillips et al., 2004), Generalized Linier Models (GLM) (Hudjimartsu et al., 2017), CLIMEX (Byeon et al., 2018), and BIOCLIM (Booth et al., 2014). The essential information in SDMs is depend on the presence and absence data occurs during the observation. However, in many conditions not all presence and absence data reliable to achieved during the incomplete data specifically for endangered species (Gomes et al., 2018)

One of the models that only require the presence of species current location is Maximum entropy (Maxent) (Gomes et al., 2018; Phillips \& Dudík, 2008). Maxent programs use present-only data and collect the information related to the environment condition at the exact point where the location of sample exist (Phillips et al., 2004). This model is broadly used for species distribution analyse in every aspect such as impacts of climate change on forest tree species (Deb et al., 2017; Rodrigues et al., 2015; Sohel et al., 2017). Moreover, Maxent is used to analyze the influences of land-use changes (Benítez-Badillo et al., 2018), species distribution assessment (Nimasow et al., 2016; Nursamsi et al., 2018) and invasive species assessment (Dermawan et al., 2018). Maxent has the advantages than other models due to presence data only for a requirement in the model, together with environmental information for the whole study area. It can utilize continuous and categorical data in the model. Furthermore, it can directly produce a map of the potential suitability area explicitly. Moreover, to evaluate the environmental variable which is considered to be important, it encompasses a jackknife test feature. Lastly, The occurrence data can be used to interpret 
the environment information and easy to use as an interface program (Phillips et al., 2008). This approach gives the huge information that reliable for the researchers to identify the potential distribution of species with additional information such as variable significant and the probability of occurrence map (Phillips et al., 2006). Indonesia SDMs has been applied in many aspects. The model is used to estimated bird distribution (Nursamsi et al., 2018) and predicted the endangered tree species distribution in Borneo (Singh, 2013). Moreover, alien invasive species in National Park using Maximum Entropy (Maxent) and Generalized Linear Model (GLM) (Dermawan et al., 2018; Hudjimartsu et al., 2017). Furthermore, the model used to analyze the threat in primate conservation. The prediction was calculated for anthropogenic risk from human intervenes (Thorn et al., 2009) and the conservation strategy for proboscis monkey in Kalimantan (Meijaard \& Nijman, 2000). However, the species distribution model still limited to know in Indonesia. Most of the research uses the SDM such as GLM, Maxent and survey analysis with a limited environmental variable. The research of SDM still limited for few species and region.

This study aims to predict the suitable area of Styrax sumatrana and analyse the environmental variable that contributed to the species distribution by applying the Maxent model in North Sumatra Region. The available of presence location and environmental data is essential for Maxent model. The information of species potential distribution of Styrax sumatrana is important as the input for the conservation strategies to protect it from the population degradation.

\section{Research Method}

Several steps were applied to predict the species distribution of Styrax sumatrana; data collection from the second and primary data, preprocessing, Maxent modeling, and postprocessing. The tools that used is GIS for spatial analysis and Maximum Entropy for Species Distribution Modeling. A simple schematic of analysis was provided in Figure 1.

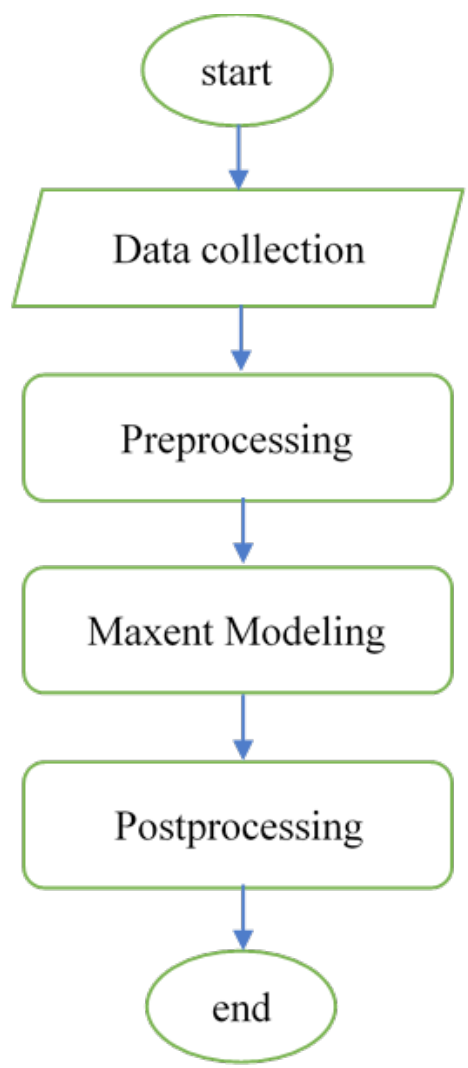

Figure 1. The Maximum Entropy model process.

\subsection{Data collection}

The data consists of species presence location and environmental condition. The presence location collected from primary and secondary data. Primary data was collected by direct observation in the field. While the secondary data was taken from several literatures (Anas \& Kholibrina, 2017b; GarcíaFernández et al., 2003; Sunandar, 2012). The number of samples is 63 individual trees with 34 primary and 29 secondary data. The data recorded the name and geographical latitude and longitude coordinate of the trees. The data for environmental variable consists of elevation, aspect, slope, land cover, climate and soil type shown in Table 1. 
Table 1. All the data used in this research as a resume.

\begin{tabular}{|c|c|c|c|c|}
\hline No & Data & Source & Type & $\begin{array}{l}\text { Extraction } \\
\text { Method }\end{array}$ \\
\hline 1 & Elevation & $\begin{array}{l}\text { www.earthexplorer. } \\
\text { usgs.gov }\end{array}$ & .tif & $\begin{array}{l}\text { Spatial } \\
\text { Analysis }\end{array}$ \\
\hline 2 & Aspect & $\begin{array}{l}\text { spatial analysis } \\
\text { from DEM data }\end{array}$ & .tif & $\begin{array}{l}\text { Analysis } \\
\text { of the } \\
\text { aspect of } \\
\text { the surface } \\
\text { topography }\end{array}$ \\
\hline 3 & Slope & $\begin{array}{l}\text { spatial analysis } \\
\text { from DEM data }\end{array}$ & .tif & $\begin{array}{l}\text { Analysis of } \\
\text { the slope of } \\
\text { the surface } \\
\text { topography }\end{array}$ \\
\hline 4 & Land cover & $\begin{array}{l}\text { www.appgis. } \\
\text { dephut.go.id }\end{array}$ &. $\mathrm{kml}$ & $\begin{array}{l}\text { Spatial } \\
\text { Analysis }\end{array}$ \\
\hline 5 & Climate & $\begin{array}{l}\text { www.worldclime. } \\
\text { org }\end{array}$ & .bil & $\begin{array}{l}\text { Spatial } \\
\text { Analysis }\end{array}$ \\
\hline 6 & Soil Type & $\begin{array}{l}\text { http://www.fao. } \\
\text { org/soils-portal }\end{array}$ & .asc & $\begin{array}{l}\text { Spatial } \\
\text { Analysis }\end{array}$ \\
\hline
\end{tabular}

\subsection{Preprocessing}

Maxent required the raster format for the environmental layer that consist of elevation, slope, aspect, soil type, temperature and land cover with same resolution, extent and geographical coordinate system. The resolution is 30 meters and the extents for environmental layers are 4.30460808352 (top), 97.0590820307 (left), 100.424402031 (right), and-0.568441916477 (bottom). The environmental layer will extract into Action Script Communication (ASC) file to be applied in Maxent program. The format in Maxent program use the Comma Separated Value (CSV) format for presence location. Furthermore, the environmental data need to be collected and selected for North Sumatra region. Nineteen bioclimatic variables (Hijmans et al., 2013 - Table. 1) with 30-second $(1 \mathrm{~km})$ spatial resolution were obtained from the WorldClim dataset (http://www.worldclim. The ArcGIS 10's used to derived these bioclimatic variables from global scale to North Sumatra region border. The data converted into raster map as Maxent requirement for analysis. Other variables are soil type, altitude, aspect and slope. Altitude was collected from the Advanced Spaceborne Thermal Emission and Reflection Radiometer Global Digital Elevation Model (ASTER GDEM). The altitude data was interpreted from the ASTER GDEM V2 dataset. The format has a 30-m spatial resolution in the Geo TIFF image and WGS84 datum (ASTER, 2004). Spatial Analysis function in ArcGIS then used to help extract Slope (as degree of an angle) and aspect (as an eight-class categorical variable: N, NE, E, SE, S, SW, W, NW), from Geo TIFF to raster format. The Sumatra soil unit was define into 43 soil unit (FAO, 1974).

\subsection{Maxent model}

Maxent is machine learning method that use the presence location as the input for analysis. Maxent programs use presence-only data and collect the information related to the environment condition at the exact point where the location of sample exist (Phillips et al., 2004). Maxent method is used to estimate a target probability distribution by finding the probability distribution of maximum entropy by considering a set of constraints that represent our incomplete information about the target distribution (Phillips et al., 2006).

Maxent model rely on Baye's rule (Phillips \& Dudík, 2008)

$P(y=1 \mid x)=\frac{P(x \mid y=1) P(y=1)}{P(x)}$

where:

$P(y=1 \mid x)$ is the probability that the species is present at the site $x$ (y ranges from $0-1$ )

$P(x \mid y=1)=\pi(x)$ is the present observation or realized distribution at $x$ area

$P(y=1)$ is the probability of presence

$P(x)=\frac{1}{|X|}$ is the all-area probability from the $\mathrm{X}$ site

Based on the Equation (1) The new formula become

$$
P(y=1 \mid x)=\pi(x) P(y=1)|X|
$$

The formula used the presence and absence information as the basis. However, the presence-only data is used in MaxEnt. This mean, the model will be implemented even the absence data is not available. Based 
on this condition, rather than estimating the Baye's estimation rule, MaxEnt use the Gibbs distribution from the sets of features $f_{1}, \ldots . ., f_{n}$ and weights ${ }_{1}, \ldots . ., n$. This distribution calculated the realized distribution () from the Baye's rule. The formula defined by (Phillips \& Dudík, 2008)100 mg/kg, i.v.

$\mathrm{q} \lambda(\mathrm{x})=\frac{\exp \left(\sum_{j=1}^{n} \lambda j f j(x)\right.}{Z \lambda}$

where:

$q \lambda(x)$ is Maxent distribution $\exp \left(\sum_{j=1}^{n} \lambda j f j(x)\right.$ is an exponential distribution parameterized by a vector of feature (f) weights .

$Z \lambda$ is a normalization constant ensuring the $q(x)$ sum to one over the area.

Due to Maxent idea is to estimate the probability of presence by maximum entropy we include the formula that delivered from Information theory by Shanon (Phillips \& Dudík, 2008)100 mg/kg, i.v.

$$
H=\Sigma q \lambda(x) \ln (q \lambda(x))
$$

where:

$H$ is maximum entropy

$q \lambda(x)$ is a MaxEnt distribution from formula (3)

After obtaining an estimate of $\mathrm{q} \lambda$, sufficient information is obtained to obtain the probability distribution $\mathrm{P}(\mathrm{y}=1 \mid \mathrm{x})$, as indicated (5).

$$
P(y=I \mid x)=\frac{\operatorname{eHq} \lambda(x)}{1+e H q \lambda(x)}
$$

\section{Where:}

$q \lambda$ is the estimated probability of presence with the maximum entropy of $\Pi$

$H$ is the entropy of $\mathrm{q} \lambda$.

\subsection{Postprocessing}

The Maxent output presented as spatial information of probability distribution of species. Furthermore, the result was interpret using ArcGIS. The spatial data from Maxent was converted into raster data by divided into categories. The categories used to identify the probability classification. The analysis converted the probability range from 0 to 1 into 5 categories referred to FAO land classification which presented the suitable area form crop plantation (Nguyen, 2008)ETM4 and ETM5 with panchromatic band. Using this output, available secondary data together with field data in order to perform a Maximum Likelihood supervised classification. Six classes of forestland were classified, namely dense forest, degraded forest, forest plantation, grass, shrub and barren land. The overall accuracy for this classification is $84.6 \%$ and Kappa index of Agreement is $82 \%$. The suitability assessment for forestry use and each tree species was conducted using the method described in FAO guidelines for land evaluation for forestry (FAO, 1984. The 5 categories presented in Table

\begin{tabular}{|c|c|c|}
\hline $\begin{array}{c}\text { Major } \\
\text { Classification } \\
\end{array}$ & Classification & $\begin{array}{c}\begin{array}{c}\text { Probability } \\
\text { values }\end{array} \\
\end{array}$ \\
\hline \multirow[t]{3}{*}{ Suitable } & Highly Suitable & $0.8-1$ \\
\hline & $\begin{array}{l}\text { Moderately } \\
\text { Suitable }\end{array}$ & $0.6-0.79$ \\
\hline & $\begin{array}{l}\text { Marginally } \\
\text { Suitable }\end{array}$ & $0.4-0.59$ \\
\hline \multirow[t]{2}{*}{ Not Suitable } & $\begin{array}{l}\text { Currently Not } \\
\text { Suitable }\end{array}$ & $0.2-0.39$ \\
\hline & $\begin{array}{l}\text { Permanently Not } \\
\text { Suitable }\end{array}$ & 0-0.19 \\
\hline
\end{tabular}
2.

The result of Maxent output changed from ASC file into raster map that easier to interpret. The raster map will divide into five class according to Table 2 . The total area converted from percentage into ha to estimate the land cover area that suitable for Styrax sumatrana. Besides the spatial result, Maxent provide the statistical analysis of variable contribution and jackknife analysis.

\section{Results and Discussion}

\subsection{Variable Contribution}

Maxent result show the variable contribution to the model. All the variable was 
calculated and arranged from the higher to the lower contribution. The three top variable that contributed for the model provided in Table 3.

Table 3. The three top variable contribution of Styrax sumatrana distribution

\begin{tabular}{clc}
\hline Variable & \multicolumn{1}{c}{ Description } & $\begin{array}{c}\text { Percent } \\
\text { contribution }\end{array}$ \\
\hline bio 11_styrax & $\begin{array}{l}\text { Mean temperature of } \\
\text { coldest quarter }\end{array}$ & 28.5 \\
alt_styrax & $\begin{array}{l}\text { Elevation } \\
\text { lulc_styarx }\end{array}$ & $\begin{array}{l}\text { Land use and land } \\
\text { cover }\end{array}$ \\
\hline
\end{tabular}

After analysing 13 environmental variable, the highest percent contribution for the model was noticed by bio 11 (the mean temperature of the coldest quarter). This variable has $28.5 \%$ contribution to predicting the potential area for Styrax sumatrana distribution in North Sumatra region. While $26.3 \%$ by elevation and $15.4 \%$ by LULC. The rest of the variables indicated a small amount of contribution for the model by least than $10 \%$ The percent contribution shows how the variable give the impact for the species to distributed among the area. The bio 11 has the highest contribution for Styrax sumatrana distribution which is important even if the other variable did not include in the analysis.

Species distribution of Styrax sumatrana is classified based on three higher variable contributions, which is (i) the mean temperature of coldest quarter, (ii) elevation and (iii) LULC. These three variables give the useful information for Species distribution among the other variable. The explanation for each variable presented below.

\subsection{Species Distribution Based on Mean Temperature of Coldest Quarter}

Based on mean temperature of coldest quarter the graphic of suitability is produced (Figure 2). The graphic shows that the suitable of species to distributed is increase from 13$19^{\circ} \mathrm{C}$ and then decrease. This result indicate that this species needs the wet season around a year with the rainfall type A or B by the Schimt and Ferguson classification and the low temperature to distributed (Jayusman, 2014).

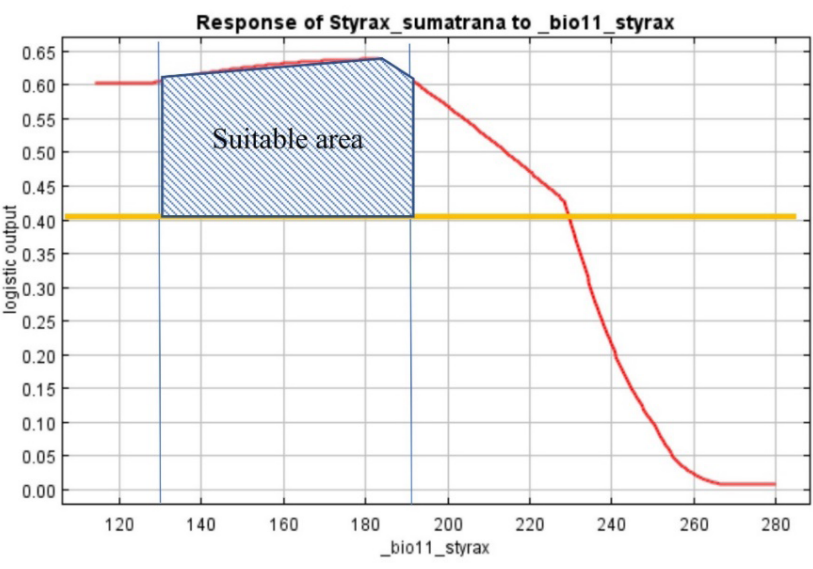

Figure 2. Response of Styrax sumatrana to mean temperature of the coldest quarter graph. The horizontal orange line in $y$ axis indicates the suitable threshold classification by 0.4 and higher probability value. The temperature value in $x$ axis multiple by 10 from the original value in Celcius degree. The red line presented the probability of species occurrence by the increment of mean temperature of the coldest quarter. While the shaded area shows the suitable condition for Styrax sumatrana to exist.

\subsection{Species Distribution Based on Elevation}

The elevation response curve shows the logistic probability of Styrax sumatrana increase from 0-1,400 meters (Figure 3). However, the suitable elevation for Styrax sumatrana distribution in North Sumatra is around $600-1,400$ meters. Based on the result, the suitable area will decrease above 1,400 meters. This result relevant with the funding from other researcher where the most of Styrax garden in North Sumatra are located above 600 meters (García-Fernández et al., 2003; Jayusman, 2014)Indonesia","title":"Mengenal Pohon Kemenyan ( Styrax spp . . Moreover, the high altitude from 500 to 1,400 meters shows the good phenotype performance for Styrax sumatrana growth (Anas \& Kholibrina, 2017b). 


\subsection{Species Distribution Based on LULC}

In the response curves of the LULC, variables produce the high logistic probability in shrub (notated by number 10) and garden (notated by number 6) land classification followed by the forest (notated by number 2) (Figure 4). The probability of shrub and garden is more than 0.6 while the forest is low by around 0.45 . The species is semi-tolerance type which needs small solar radiation from the sun to grow. Yet, the solar radiation requirement will increase following the increase of volume (Anas \& Kholibrina, 2018). The shrub area was suitable for this condition. Furthermore, the competition of nutrient in shrub area was less rather than in forest.

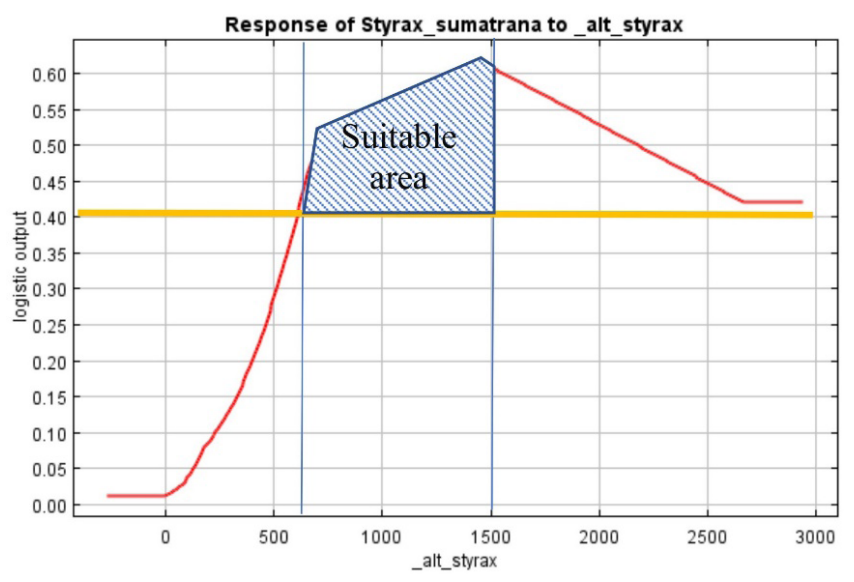

Figure 3. Response of Styrax sumatrana to altitude graph. The horizontal orange line in $y$ axis indicates the suitable threshold classification by 0.4 and higher probability value. The altitude value in $x$ axis presented the altitude in meter above sea level. The red line presented the probability of species occurrence by the increment of altitude. While the shaded area shows the suitable condition for Styrax sumatrana to exist.

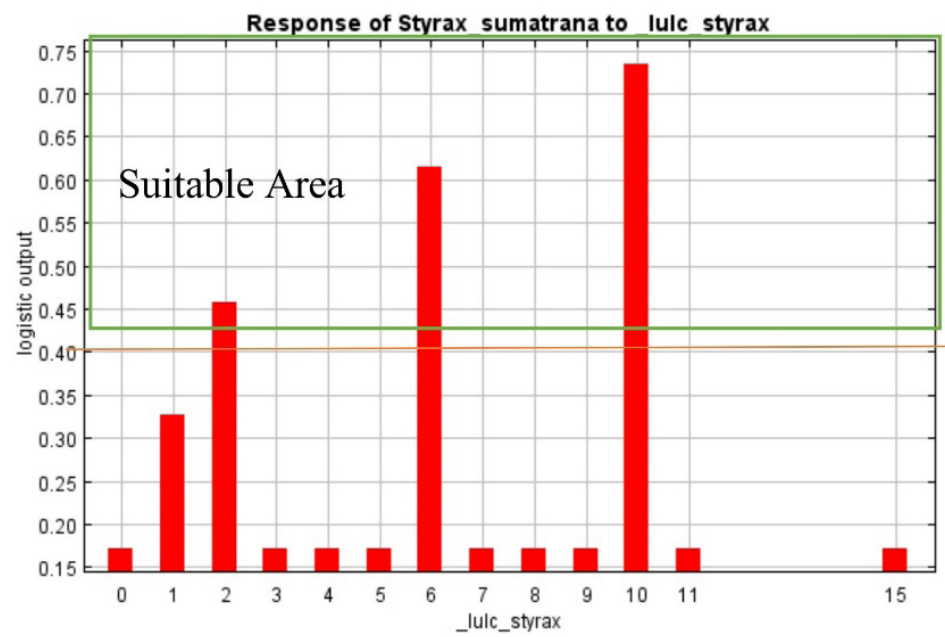

Legend:
0. Airport
1. Crop
2. Forest
3. Lake
4. Mangrove
5. Open area
6. Garden
7. Plantation forest
8. Pond
9. Residental
10. Shrub
11. Swam

Figure 4. Response of Styrax sumatrana to LULC. The horizontal orange line in y axis indicates the suitable threshold classification by 0.4 and higher probability value. The LULC classification in $x$ axis explained in the legend. The red line presented the probability of species occurrence by the different LULC classification. While the shaded area shows the suitable condition for Styrax sumatrana to exist. 


\subsection{Potential Distribution of Styrax} sumatrana

The result of Styrax sumatrana distribution is presented in Figure 5. The Suitable area for this species was $8.91 \%$ or around $663,221.94$ ha from the total of North Sumatra. Meanwhile, data from agriculture agency of North Sumatra showed that the total area of Styrax Garden only 22,912.13 ha in 2017 (Dinas Perkebunan Sumatera Utara, 2018). It means that the potential area is high rather than the current area for Styrax sumatrana garden.

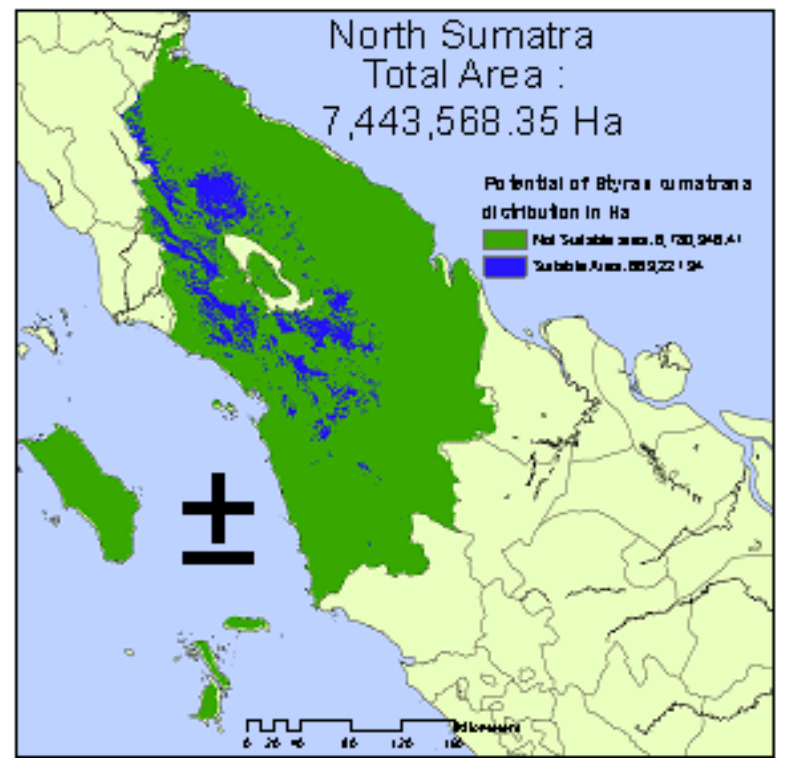

Figure 5. The map of suitable area for Styrax sumatrana in North Sumatra Province.
The central of Styrax sumatrana garden mostly distribute in three Sub-region which are Tapanuli Utara, Toba Samosir, Dairi, Humbang Hasundutan and Pakpak Barat (Dinas Perkebunan Sumatera Utara, 2018). Meanwhile, the maxent result shows that Karo regency has a high potential for Styrax sumatrana.

\subsection{Validation}

The model evaluation was presented in Maxent output as Receiver Operating Characteristic (ROC) curve. The ROC curve is a graph showing the performance of a classification model at all classification thresholds. The ROC curve consists of sensitivity and 1-sensitivity that showed in Figure 6.

The result showed that the Area Under Curve (AUC) number is 0.949. A high AUC indicates that sites with high predicted suitability values tend to be areas of known presence. An AUC score of 0.5 means that the model is as good as a random guess (Hijmans \& Elith, 2013). The highest value in AUC describes the best model by considered all variable that used in the model and the lower than 0.5 show the model not even good rather than random prediction.

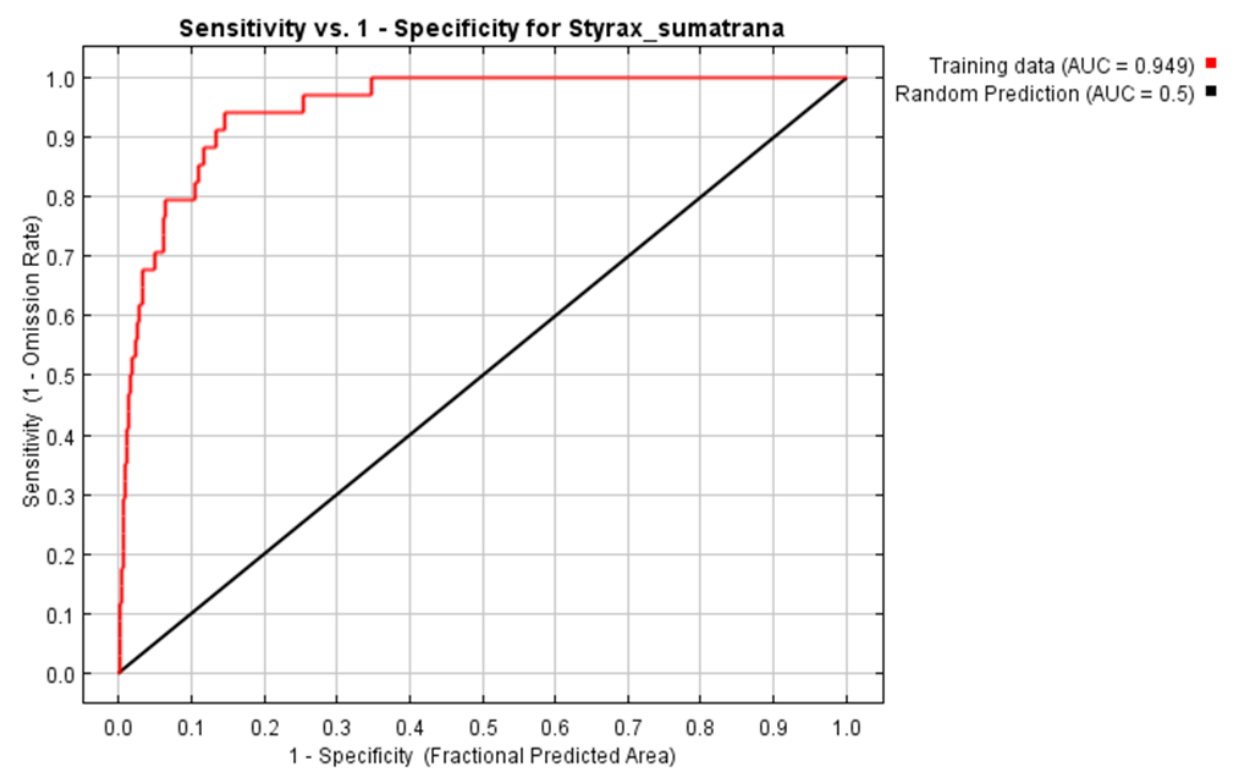

Figure 6. The Sensitivity and 1-sensitivity graph of Styrax sumatrana 


\subsection{Discussion}

The models estimated the potential distribution of Styrax sumatraThe models estimated the potential distribution of Styrax sumatrana in North Sumatra with the highest validation based on ROC analysis. The model provides a statistical analysis that shows the percent contribution of every variable that include in the calculation. Three major variables that contributed to the model most decide the potential distribution of the species. The variables inform the suitable area which has a similar condition with the occurrence species in the area. Furthermore, in a geographical pattern, Styrax sumatrana has been distributed around LTCA as a garden for more than century. The temperature, altitude and LULC describe the sufficient condition for the distribution of the species.

Mean temperature in coldest quarter provides the seasonal distribution of Styrax sumatrana effected by low temperature. The research shows the impact of temperature to tree growth due to evaporation increment in tropical forest (Wright et al., 2009). Small increment of temperature may reduce the probability distribution of this species (Herold, 2017). The result from Maxent analysis provide the high importance of mean temperature of the coldest quarter variable to the model. This means that the variable can explain the potential distribution of Styrax sumatrana without considering the other variable. The result is similar with the finding from the study of Dysoxylum binectariferum by Sohel et al (2017) in Bangladesh. Mean temperature in the coldest quarter provides the highest contribution to the model (Sohel et al., 2017).

The mean temperature in coldest quarter index calculated based on the summed average temperatures of each month in the quarter. Thus, the quarter with the lowest value is selected (O'Donnell \& Ignizio, 2012). The coldest temperature in Indonesia is fall between last September until November (BMKG, 2015). In this quarter Styrax sumatrana flowering phase was passed and the fruit was occur (Kholibrina et al., 2018). The abundance genetic material is available in this quarter which is increase the probability for distribution of Styrax sumatrana.

The high altitude mean the temperature become colder which is important variable for the Styrax sumatrana distribution (Sunandar, 2012). Based on the first environment variable, the temperature increases the distribution probability of Styrax sumatrana. The comparison with other species in same Styrax Genus shows the same condition. From the other species of Styrax the distribution of species is occur in high elevation $(1,100$ 1,500 meters above sea level) such as Styrax wuyuanensis in North America and Styrax nicaraguensis in Costa Rica and Nicaragua. Eventhough the distribution of the species has a wide range from low to high altitude, the better performance of yield and phenology are presented in elevation above 600 to 1,500 meters (Anas \& Kholibrina, 2018; Sunandar, 2012; Susilowati et al., 2018).

Styrax sumatrana has been cultivated more than 200 years. Since that time, the Styrax has been established as plants in the garden and used by the farmer in North Sumatra. Although it has been cultivated, the distribution in forests and shrub areas still exist (GarcíaFernández et al., 2003). The Styrax sumatrana found in the small population in forest area than in cultivated (García-Fernández et al., 2003; Puspitaningtyas, 2005). The probability distribution in the garden has a higher value than the forest due to the intensive cultivation. However, intensive management reduces the diversity of large tree. The shrub area is the ex-intensive cultivation garden which is abandoned by the farmer. In this area, the number of seedlings and natural regeneration increase the probability of distribution rather than in garden which is the area limited and less natural regeneration was occur (GarcíaFernández et al., 2003).

Based on the result, Styrax sumatrana has the future potential as the garden in a wider area. Regarding the result, most of the abandoned area that became shrub can be cultivated as the garden and this also help 
farmer to generate more income. The Styrax sumatrana plantation as a garden will protect the LTCA from erosion by strap the soil. Finally, the plantation program in suitable area will enhance the area to be more productive and beneficial for the farmer and environment.

\section{Conclusion and Recommendation}

\subsection{Conclusion}

This paper has conducted model that can predict the potential area of Styrax sumatrana in North Sumatra using Maximum Entropy modeling approach. Based on AUC result of 0.949 , the model can be classified as very well prediction. Three most influence environmental variable for Styrax sumatrana distribution were mean temperature in coldest quarter $(28.5 \%)$, elevation (26.3\%) and LULC (15.4\%). It explains that Styrax sumatrana distributed across the area from high altitude, lower temperature with high precipitation. The suitable area for Styrax sumatrana is wider than the current Styrax garden existing area. Only 22,912.13 ha area was developed as the styrax garden, while there are 553,221.94 ha area is suitable for this species cultivation. Most of the suitable area is still abandon such as the open area and shrub. Furthermore, the prediction of climate change can be used to predict the distribution of Styrax sumatrana in future scenario.

\subsection{Recommendation}

Maxent presents the result of high potential area in Karo regency and around LTCA. The potential area for Styrax sumatrana was recorded in around LTCA and the northern part of North Sumatra Province. With a large amount of potential area compare to the current plantation, there is high opportunity for the authority to enrichment the area to be more productive by reforestation using Styrax sumatrana. Due to the advantages of this species as the non-timber product and the ecological benefit, the authority needs to consider this species as the prospective species to develop in North Sumatra. This species will also be able to support farmer's additional income sources.

\section{Acknowledgements}

The first author would like to thank the Ministry of Environment and Forestry and Planning Agency, Indonesia, for their support in this research. Finally, this study based on the Double Degree Thesis between ITB and Hiroshima University.

\section{References}

Anas, A., \& Kholibrina, C. R. (2017a). Estimation models for incense resin productivity (Styrax sumatrana J.J. SM) in North Sumatra. Jurnal Penelitian Kehutanan Sumatrana Jurnal, 1(1), 10-21.

Anas, A., \& Kholibrina, C. R. (2017b). Faktor-faktor Fenotipe dan Lingkungan Penentu Produktivitas Resin Kemenyan Toba (Styrax sumatrana J. J. Sm). Jurnal Penelitian Kehutanan Sumatrana, 1(1), 1-9.

Anas, A., \& Kholibrina, C. R. (2018). Growth and yield model for non-timber forest product of kemenyan (Styrax sumatrana J . J . Sm ) in Tapanuli , North Sumatra. In IOP Conference Series: Earth and Environmental Science 122 012036. IOP Publishing. https:/ / doi.org/10.1088/17551315/122/1/012036

ASTER. (2004). ASTER Global Digital Elevation Map. Retrieved August 16, 2019, from https:// asterweb.jpl.nasa.gov/gdem.asp

Austin, M. (2007). Species distribution models and ecological theory: A critical assessment and some possible new approaches. Ecological Modelling, 200(1-2), 1-19. https://doi. org/10.1016/j.ecolmodel.2006.07.005

Benítez-Badillo, G., Lascurain-Rangel, M., Álvarez-Palacios, J. L., Gómez-Díaz, J. A., Avendaño- 
Reyes, S., Dávalos-Sotelo, R., \& López-Acosta, J. C. (2018). Influence of Land-Use Changes (1993 and 2013) in the Distribution of Wild Edible Fruits From Veracruz (Mexico). Tropical Conservation Science, 11, 1-11. https:/ / doi.org/10.1177/1940082918758662

BMKG. (2015). www.dataonline.bmkg.go.id.

Booth, T. H., Nix, H. A., Busby, J. R., \& Hutchinson, M. F. (2014). Bioclim: The first species distribution modelling package, its early applications and relevance to most current MaxEnt studies. Diversity and Distributions, 20(1), 1-9. https:/ / doi.org/10.1111/ddi.12144

Byeon, D., Jung, S., \& Lee, W.-H. (2018). Review of CLIMEX and MaxEnt for studying species distribution in South Korea. Journal of Asia-Pacific Biodiversity, 11(3), 325-333. https:// doi. org/10.1016/J.JAPB.2018.06.002

Deb, J. C., Phinn, S., Butt, N., \& McAlpine, C. A. (2017). The impact of climate change on the distribution of two threatened Dipterocarp trees. Wiley Ecology and Evolution, 1-11.

Dermawan, B. A., Herdiyeni, Y., Prasetyo, L. B., \& Siswoyo, A. (2018). Predicting the spread of acacia nilotica using Maximum Entropy modeling. Telkomnika (Telecommunication Computing Electronics and Control), 16(2). https://doi.org/10.12928/telkomnika.v15i4.6894

Dinas Perkebunan Sumatera Utara. (2018). Aplikasi Entry Data Statistik Perkebunan Sumatera Utara. Data Luas Areal, Produksi dan Produktivitas Perkebunan Rakyat Tahun 2017 Komoditi Kemenyan. Retrieved from http://disbun.sumutprov.go.id/statistik_2019/ web/index.php?r=site\%2Fcetak-laporan-komoditi\&tahun=2017\&kabupaten=6\&komodit as $=8$

Gaol, E. D. L., \& Simangunsong, B. C. H. (2012). Analisis Profitabilitas dan Tataniaga Kemenyan di Desa Sampean Kabupaten Humbang Hasundutan Sumatera Utara ( Profitability and Market Chain Analyses of Sumatera Benzoin at Sampean Village District of Humbang Hasundutan North Sumatera Province ). Journal Ilmu Dan Teknologi Kayu Tropis, 10(2), 130138.

García-Fernández, C., Casado, M. A., \& Ruiz Pérez, M. (2003). Benzoin gardens in North Sumatra, Indonesia: Effects of management on tree diversity. Conservation Biology, 17(3), 829-836. https://doi.org/10.1046/j.1523-1739.2003.01487.x

Gomes, V. H. F., Ijff, S. D., Raes, N., Amaral, I. L., Salomão, R. P., Coelho, L. D. S., ... Ter Steege, H. (2018). Species Distribution Modelling: Contrasting presence-only models with plot abundance data. Scientific Reports, 8(1), 1-12. https:/ / doi.org/10.1038/s41598-017-18927-1

Herold, B. (2017). Facing an Uncertain Future. Education Week (Vol. 37). https:/ / doi.org/10.17528/ cifor $/ 002600$

Hijmans, R. J., \& Elith, J. (2013). Species distribution modeling with R Introduction. Encyclopedia of Biodiversity, 71. https://doi.org/10.1016/S0550-3213(02)00216-X

Hudjimartsu, S. A., Herdiyeni, Y., Prasetyo, L. B., \& Siswoyo, A. (2017). Prediction of The Spread of Acacia nilotica Invasive Species Using Generalized Linear Models. Jurnal Manajemen Hutan Tropika, 23, 150-157. https://doi.org/10.7226/jtfm

Jayusman. (2014). Mengenal Pohon Kemenyan ( Styrax spp . ). (M. Na'iem, Mahfudz, \& S. Prabawa, Eds.). Jakarta, Indonesia: IPB Press.

Kholibrina, C. R., Anas, A., \& Susilowati, A. (2018). Flowering and fruiting phenology of Kemenyan toba ( Styrax sumatrana J . J . Sm .) in AekNauli. In IOP Conference Series: Earth and Environmental Science 122 (2018) 012061. 
Meijaard, E., \& Nijman, V. (2000). Distribution and conservation of the proboscis monkey (Nasalis larvatus) in Kalimantan, Indonesia. Biological Conservation 92, 92, 15-24.

Miller, J. (2010). Species distribution modeling. Geography Compass, 4(6), 490-509. https://doi. org/10.1111/j.1749-8198.2010.00351.x

Nguyen, V. L. (2008). Use of GIS Modelling in Assessment of Forestry Land's Potential in Thua Thien Hue Province of Central Vietnam. (Doctoral Dissertation, Niedersächsische Staats-Und Universitätsbibliothek Göttingen).

Nimasow, G., Nimasow, O. D., Rawat, J. S., Tsering, G., \& Litin, T. (2016). Remote sensing and GIS-based suitability modeling of medicinal plant (Taxus baccata Linn.) in Tawang district, Arunachal Pradesh, India. Current Science, 110(2), 219-227. https://doi.org/10.18520/cs/ v110/i2/219-227

Nursamsi, I., Partasasmita, R., \& Cundaningsih, N. (2018). Modeling the predicted suitable habitat distribution of Javan hawk- eagle Nisaetus bartelsi in the Java Island , Indonesia. Biodiversitas, 19(4), 1539-1551. https:/ / doi.org/10.13057/biodiv/d190447

O’Donnell, M. S., \& Ignizio, D. A. (2012). Bioclimatic Predictors for Supporting Ecological Applications in the Conterminous United States. U.S Geological Survey Data Series 691, 10.

Phillips, S. J., Anderson, R. P., \& Schapire, R. E. (2006). Maximum entropy modeling of species geographic distributions. Ecological Modelling, 190, 231-259. https://doi.org/10.1016/j. ecolmodel.2005.03.026

Phillips, S. J., \& Dudík, M. (2008). Modeling of species distribution with Maxent: new extensions and a comprehensive evalutation. Ecograpy, 31, 161-175. https://doi.org/10.1111/ j.2007.0906-7590.05203.x

Phillips, S. J., Dudík, M., \& Schapire, R. E. (2004). A maximum entropy approach to species distribution modeling. Twentyfirst International Conference on Machine Learning ICML 04, 69, 83. https://doi.org/10.1145/1015330.1015412

Prasad, A. M., Iverson, L. R., Matthews, S. N., \& Peters, M. P. (2016). A multistage decision support framework to guide tree species management under climate change via habitat suitability and colonization models, and a knowledge-based scoring system. Landscape Ecology, 31(9), 2187-2204. https:/ / doi.org/10.1007/s10980-016-0369-7

Puspitaningtyas, D. M. (2005). Flora Sumatera Utara Eksotik dan Berpotensi. Bogor: Pusat Konservasi Tumbuhan Kebun Raya Bogor, LIPI.

Rodrigues, P. M. S., Silva, J. O., Eisenlohr, P. V., \& Schaefer, C. E. G. R. (2015). Climate change effects on the geographic distribution of specialist tree species of the Brazilian tropical dry forests. Brazilian Journal of Biology, 75(3), 679-684. https:/ / doi.org/10.1590/1519-6984.20913

Silalahi, J., \& Sunandar, A. D. (2017). Kemenyan ( Styrax spp .) Getah Berharga Tano Batak. Forestry Research of Aek Nauli.

Singh, M. (2013). Predictive modelling of the distribution of two critically endangered Dipterocarp trees: Implications for conservation of riparian forests in Borneo. Journal of Ecology and The Natural Environment, 5(9), 254-259. https:// doi.org/10.5897/JENE2013.0383

Sohel, S. I., Akhter, S., Ullah, H., Haque, E., \& Rana, P. (2017). Predicting impacts of climate change on forest tree species of Bangladesh: Evidence from threatened Dysoxylum binectariferum (Roxb.) Hook.f. ex Bedd. (Meliaceae). IForest, 10(1), 154-160. https://doi.org/10.3832/ ifor1608-009 
Sunandar, A. D. (2012). Peta Kesesuaian Jenis Kemenyan ( Styrax spp .) di Sumatera Utara ( Utilization of Geographic Information System to Develop Land Suitability Map for Styrax spp . in North Sumatera ). Jurnal Penelitian Hutan Tanaman, 9, 63-73.

Susilowati, A., Khoilibrina, C. R., Rachmat, H. R., \& Munthe, M. A. (2018). Phylogeny of kemenyan ( Styrax sp.) from North Sumatra based on morphological characters Phylogeny of kemenyan (Styrax sp .) from North Sumatra based on morphological characters. Environmental Science.

Thorn, J. S., Nijman, V., Smith, D., \& Nekaris, K. A. I. (2009). Ecological niche modelling as a technique for assessing threats and setting conservation priorities for Asian slow lorises (Primates: Nycticebus). Diversity and Distributions, 15(2), 289-298. https://doi.org/10.1111/ j.1472-4642.2008.00535.x

Wright, S. J., Muller-Landau, H. C., \& Schipper, J. (2009). The Future of Tropical Species on a Warmer Planet. Journal Compilation C, 23(6), 1418-1426. https://doi.org/10.1111/j.15231739.2009.01337.x 